\title{
プラズマ重合膜と光の機能
}

\section{稲垣 訓宏}

Norihiro Inagaki, 静岡大学工学部

\section{1.はじめに}

グロー放電中にガス状となった有機化合物を吹き込 むと、フィルム状のポリマーが得られる。プラズマ重 合とよばれるこのポリマー合成法は，新しい薄膜製造 法・表面処理法の一つとして利用されている。この重 合法はグロー放電中に存在する数干度（電子温度）に も及ぶ電子・ラジカル・イオンの高エネルギーをポリ マ一生成の源とし, 従来の重合法とは多少様子を異に している. (1)官能基をもたない化合物からでもポリマ 一が生成する (2)モノマーから直接基板表面に薄膜が 析出する (3)グロー放電状態を変えることによって, 同一モノマーから性質を異にするポリマーが生成する ことなどが特筆すべき特徵である。

本稿ではプラズマ重合の基本的考え方と，二，三の 機能性薄膜合成への試みについて述べることとする.

\section{2. プラズマ重合から生成するポリマー}

プラズマ重合では官能基をもたないメタン・エタン などからでもポリマーが生成することはすでに述べ た。この特徴はポリマー生成過程が通常の重合反応と 異なっていることを予想させる. Yasuda ら ${ }^{1)}$ は十数 種の化合物から生成したプラズマポリマーの元素組成 を比較した，例えば，エチレンおよびアセチレンから のプラズマポリマーはそれぞれ $\mathrm{C}_{2} \mathrm{H}_{2.6} \mathrm{O}_{0.4}, \mathrm{C}_{2} \mathrm{H}_{1.6}$ $\mathrm{O}_{0.3}$ の元素組成であった。この元素組成は出発物質で あるエチレン・アセチレンの元素組成 $\mathrm{C}_{2} \mathrm{H}_{4} \cdot \mathrm{C}_{2} \mathrm{H}_{2}$ と 異なっている。総じて，プラズマポリマーはモノマー の元素組成に比べ, 水素含量が低く, 少量の酸素を含 んでいる。もしエチレンの二重結合の開裂によってポ リマーが生成したとすると，

$$
\begin{gathered}
\left.\mathrm{CH}_{2}=\mathrm{CH}_{2} \longrightarrow+\mathrm{CH}_{2} \cdot \mathrm{CH}_{2}\right)_{n} \\
\mathrm{H} / \mathrm{C}=2 \\
\mathrm{H} / \mathrm{C}=2 \text { となり, }
\end{gathered}
$$

Plasma-Polymer Films and their Functions
生成したプラズマポリマーの元素組成は末端基を無視 できるとすればモノマーのそれと変わらないはずであ る. 実験結果はプラズマポリマ一の元素組成とモノマ 一のそれとの間に大幅な差が生じていることを示して いる、したがって，プラズマ重合では単に二重結合を 経てポリマー鎖が成長するのではないと思われる.

さらに, Yasuda ら21はビニル基をもつモノマーと もたないモノマーのポリマー析出速度を比べた. 重合 速度定数に相当するプラズマ重合におけるポリマー析 出速度定数を比べてみると，ビニル基の存在に関係な

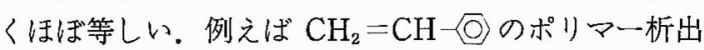
速度定数 $(k)=5.65$ に対し $\mathrm{CH}_{3} \cdot \mathrm{CH}_{2}$ であり, $\mathrm{CH}_{2}=\mathrm{CH}-\mathrm{CN}$ の $k=5.71$ に対し $\mathrm{CH}_{3} \cdot \mathrm{CH}_{2}$ - $\mathrm{CN}$ では $k=4.49$ となった. また, $\mathrm{CH}_{2}=\mathrm{CH} \cdot \mathrm{CH}_{2}$ $\mathrm{NH}_{2}$ では $k=2.86$ に対し $\mathrm{CH}_{3} \cdot \mathrm{CH}_{2} \cdot \mathrm{CH}_{2} \mathrm{NH}_{2}$ では $k=2.5$ であった，以上の結果は，ポリマー形成につ いてモノマーの化学構造の影響は少ないことを示唆し ている。

\section{3. プラズマポリマーの生成機構}

プラズマ重合の特異な点を $2 . て ゙$ 述べたが，ではど んな経路でポリマー生成がなされているのであろう か.この問題はまだ完全に解明されたわけではない. しかし，フッ素化合物からのプラズマポリマーの ESCA スペクトルは一つのヒントを与えているよう

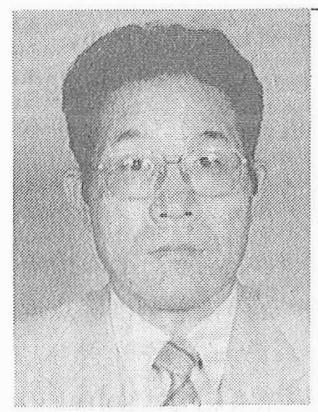

稻垣訓宏 静岡大学工学部材料 精密化学科 (432 浜松市城北 3 -5-1）教授. 工博

昭和 41 年静岡大大学院工学研 究科修了. 41 年静岡大工学部 助手, 46 年講師, 49 年助教授 を経て 60 年より教授。53〜 54 年ミズリー大学口ーラ校 (Prof. Yasuda) 留学. 専門は プラズマ重合, 機能性薄膜, 有 機電子材料。

〈趣味〉テニス 
である。

図1はテトラフルオロエチレン (TFE) およU゙パー フルオロメチルシクロヘキサン $(\mathrm{PFMCH})$ からプラ ズマポリマーの $\mathrm{ESCA}\left(\mathrm{C}_{1 \mathrm{~s}}\right)$ スペクトルである3. $\mathrm{C}_{1 \mathrm{~s}}$ スペクトルには両ポリマーの炭素鎖の微細構造がよく 現われており，低エネルギー側より $\mathrm{CF}, \underline{\mathrm{CF}}-\mathrm{CF}_{n}$, $\mathrm{CF}_{2}, \underline{C F}_{3}$ 基と帰属される.これら炭素鎖単位の相対 量はそれぞれ 25\%ずつであった，もし，TFEの二重 結合，あるいは $\mathrm{PFMCH}$ のシクロへキサン環の開裂 によってポリマー鎖が生成したとすると，TFE から は- $\left.-\mathrm{CF}_{2} \cdot \mathrm{CF}_{2}\right)$ 単位が, $\mathrm{PFMCH}$ からは $\mathrm{f}(\mathrm{CF})_{5} \cdot \mathrm{CF}$ $\left(\mathrm{CF}_{3}\right)$ 子単位をもつポリマー鎖がそれぞれ生成するは ずである。したがって， $\mathrm{C}_{1 \mathrm{~s}}$ スペクトルは TFE から のポリマーでは $\mathrm{CF}_{2}$ 単位が $100 \%, \mathrm{PFMCH}$ からの ポリマーでは $\underline{\mathrm{CF}}-\mathrm{CF}_{n}$ 単位が $14.3 \%(1 / 7), \mathrm{CF}_{2}$ 単 位が $71.4 \%(5 / 7), \mathrm{CF}_{3}$ 単位が $14.3 \%(1 / 7)$ の構 成を示すはずである，図 1 の結果はこの予想とは大幅 に相違している。この $\mathrm{C}_{1 \mathrm{~s}}$ スペクトルの結果を与える には, ポリマ一生成過程で $\mathrm{C}-\mathrm{F}$ 結合の切断と, $\mathrm{F}$ 原 子の再配列が起こらねばならない.

以上の結果から，プラズマ重合におけるポリマー生 成過程を次のよjに推定することができる，グロ一放 電中に吹きこまれたモノマー分子はフラグメンテーシ ヨンを受け，続いて再配列を経てポリマーが生成する のであろう。

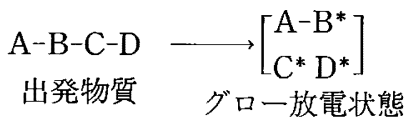

$$
\begin{array}{ccc}
\mathrm{A}-\mathrm{B}= & \mathrm{D}-\mathrm{A}-\mathrm{B}-\mathrm{B}-\mathrm{P}_{\mathrm{P}}^{\mathrm{A}}-\mathrm{D}- \\
\mathrm{C} & \mathrm{D}_{1} & \mathrm{~B} \\
& & \text { 生成ポリマー }
\end{array}
$$

すなわち, 出発物質としてのモノマー分子はいった んフラグメンテーションを受けるので, 生成したポリ マ一鎖を構成している原子の配列はモノマーのそれと はかなり変わってくることになる，言い換えれば，プ ラズマポリマーの化学構造はグロー放電中でモノマー 分子がどのようにフラグメンテーションを受けるかに 強く影響を受けることになる。したがって，機能性プ ラズマポリマーの合成はこのフラグメンテーションを いかに望む方向に導くかにかかっている。

\section{4. プラズマ重合の反応規制}

プラズマ重合におけるモノマーのフラグメンテーシ ヨンの重要性を述べたが, このフラグメンテーション の程度はプラズマのエネルギーに深く関係することは

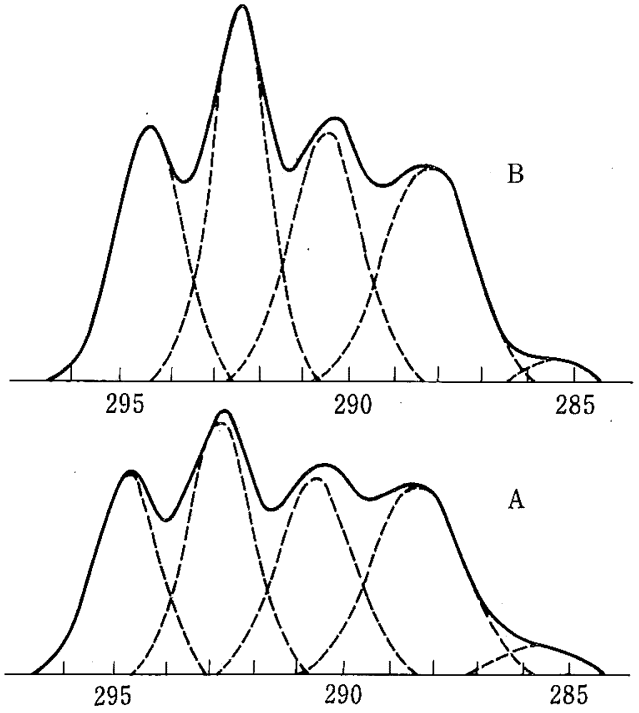

結合エネルギー/eV

\begin{abstract}
$\mathrm{A}$ ：テトラフルオロエチレンからのプラズマポリマー
B ：パーフルオロメチルシクロヘキサンからのプラズ マポリマー
\end{abstract}

図 1 ESCA (C18) スペクトル

もちろん，モノマーの化学構造にも関係が深い.

Yasuda $^{4)}$ はプラズマエネルギーの尺度として， $W / F M$ パラメーターを提案している。ここで，W は rf (radio frequency) 出力, $F$ はモノマー流量, $M$ はモノマー分子量であり, $W / F M$ 值はモノマー 分子に与えられた見掛けの $\mathrm{rf}$ エネルギーを表わして いる. 高い $W / F M$ 值でのプラズマ重合操作ではフ ラグメンテーションを激しく受けたポリマーが生成す ることになる。逆に, 低い $W / F M$ 值ではモノマー の化学構造を残したポリマーが生成する.

アクリル酸・メタクリル酸に代表されるカルボキシ ル基を有する化合物からのプラズマポリマーにはカル ボキシル基の保有は難しい，これはカルボキシル基が グロー放電中で脱 $\mathrm{CO}, \mathrm{CO}_{2}$ 反応を起こすためであ る.このフラグメンテーションは $\mathrm{CO}_{2}$ を共存させた 系でグロー放電を行なうと抑制することができる5. もち万ん低い電子温度でのプラズマを用いれば同様の 抑制効果が得られる。

逆に，モノマー中の特定の基のフラグメンテーショ ンに強い感受性を利用して反応規制が可能となる。メ トキシ基のその感受性を利用したジメトキシジメチル シランからのジメチルシロキサン構造をもつプラズマ ポリマー合成がこの例である6).これらの例はモノマ 一の選択の重要性を再認確させるものである. 


\section{5. モノマー混合系のプラズマ重合}

3. で推定したプラズマポリマー生成経路から，2 種 のモノマーの混合ガスをグロー放電中に吹き込むと， 混合物組成に依存した一種のコポリマーが生成するで あろう。この予想は窒素/水蒸気／エチレンの 3 種混 合物から親水性プラズマの形成によって確められ $た^{77}$. 疎水性表面を与えるテトラメチルシランと親水 性表面を与えるアンモニアガスの混合物から得られた プラズマポリマーの表面エネルギーはアンモニア濃度 の増加とともに $24 \mathrm{dyn} \cdot \mathrm{cm}^{-1}$ からほぼ直線的に 44 $\mathrm{dyn} \cdot \mathrm{cm}^{-1}$ まで増加する ${ }^{8)}$.このように性質の異なる 化合物の混合物を出発物質とすると, 生成したプラズ マポリマーの物性值を連続的に変化させることが可能 となる.この手法は高機能性材料開発の際に有力とな るであろう。

\section{6. 機能性プラズマポリマー}

\section{6-1. 分離膜}

瞙の薄さを利用してプラズマポリマー瞙を液体ある いはガス分離へ応用しようとする試みは数多い. 古く は逆浸透膜9), 近頃ではガス分離膜, 特に酸素富化膜 への利用が盛んである。酸素富化膜には酸素と親和性 の強いフッ素化合物 ${ }^{10)}$ ，あるいは酸素透過速度の高い シリコン化合物 ${ }^{11)}$ をプラズマ重合の出発物質として いる。これらの中には酸素と窒素の透過係数比が 4 近 いものが得られている。

著者ら ${ }^{12)}$ はフッ素化合物にポリマーの凝集エネル ギー密度を高めるためアンモニアガスあるいはメタン を混合した系からのプラズマポリマーを多孔質膜上に 析出させた。この複合膜を用いると, 酸素/窒素混合 ガス ( $20 \%$ 酸素濃度) を酸素濃度約 $50 \%$ まで濃縮で きる。

酸素富化膜の外に，ジシクロヘキシル-18-クラウン -6からのプラズマポリマー膜を用いた K イオンの輸 送 ${ }^{13)}$, カンファーあるいはメントールからのプラズマ ポリマー膜による光学活性物質の分離 ${ }^{14)}$ など特殊な 機能をもつ膜が開発されている。

\section{6-2. 化学センサ}

窒素残基を有するプラズマポリマーは親水性表面と なることは前に述べたが，この性質を発展させると， ふん囲気の湿度変化に対して表面抵抗が变わる，実際 にはテトラメチルシラン/アンモニアガスの混合, あ るいはビス（ジメチルアミノ）メチルビニルシランな どの含窒素シリコン化合物からのプラズマポリマーを さらにメチルブロマイドで四級アンモニウム塩とした ものが湿度センサ素子として効果が優れている15). 図

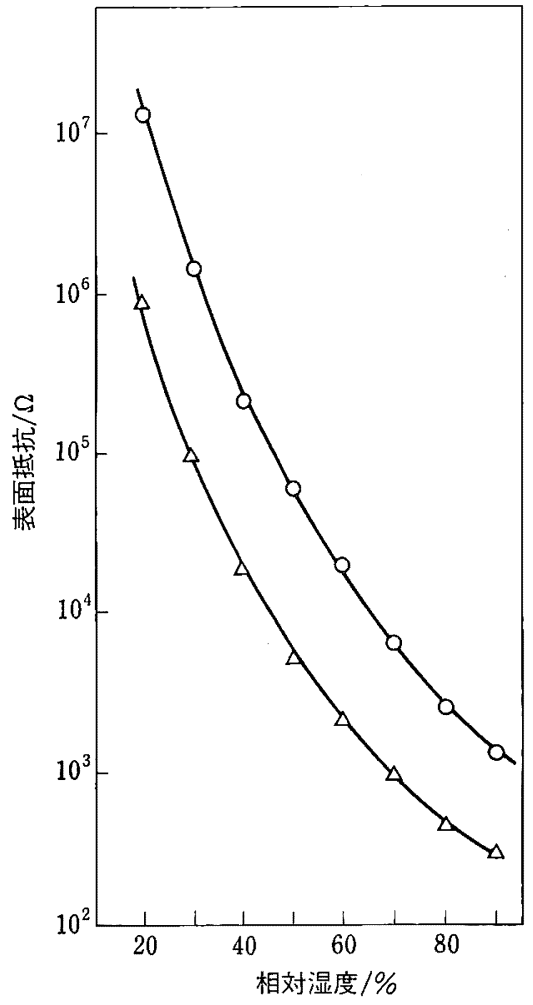

○：テトラメチルシラン/アンモニア混合ガスか らのプラズマポリマー

$\triangle$ :ビス（ジメチルアミノ）メチルビニルシラン からのプラズマポリマー

図 2 プラズマポリマーの感湿特性

2 はその一例を示したものであり，相対湿度 20～90\% の範囲で表面抵抗は $10^{4} \Omega$ 程度変化する。応答も数秒 以内に完結し, 薄膜を感湿材として用いたため周期的 に湿度変化を繰り返したときの表面抵抗のヒステリシ スもほとんど無視できる。

\section{6-3. 金属を含有するプラズマポリマー}

官能基をもたない化合物からでも簡単にポリマーを 得ることができるプラズマ重合の特徵を利用すると， 有機金属化合物から金属を含有した特殊な機能をもつ プラズマポリマーが得られる、テトラメチルスズを出 発物質とした導電性ポリマー(導電率 $2 \times 10^{-1} \sim 1 \times$ $\left.10^{-2} \Omega^{-1} \mathrm{~cm}^{-1}\right)^{16)}$ あるいはプロパンガスに感応するプ ラズマポリマー17) が報告されている。図3はその一 例を示したものであり，プロパン濃度 100 ～5,000 ppm の範囲で計測が可能である.

また, フタロシアニン化合物からは半導体的性質を 示すプラズマポリマーの生成の報告もなされてい $ろ^{18)}$. 


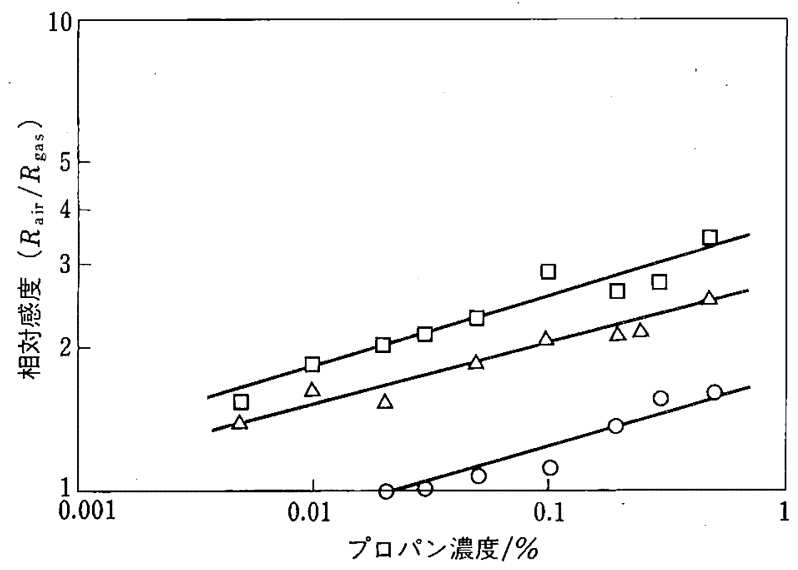

図 3 プラズマポリマーのプロパン感応特性

測定温度 $\bigcirc: 300^{\circ} \mathrm{C}$

$\square: 350^{\circ} \mathrm{C}$

$\triangle: 400^{\circ} \mathrm{C}$

\section{7. まと め}

プラズマ重合に対する基本的な考え方と，二，三の 応用について紹介した.プラズマ重合は 3 次元橋かけ したポリマーの生成と，ポリマー薄膜の形成に特色が ある。薄膜化，あるいは表面の特殊な機能発現に今後 の研究の発展に期待がよせられている，高機能性プラ ズマポリマー薄膜の分子設計には，グロー放電中にお けるモノマー分子の挙動の解明, プラズマ状態の計 測，制御が是非とも不可欠である。これには化学以外 に物理・電気分野との連携が必要である。

なお，リビング的に重合が進行するプラズマ開始重 合，およびプラズマグラフト重合については紙面の関 係でふれることができなかった。

\section{文献}

1) H. Yasuda, C.E. Lamaze: J. Appl. Polym. Sci., 17, 1519 (1973)

2) H. Yasuda, C.E. Lamaze: J. Appl. Polym. Sci., 17, 1533 (1973)

3) N. Inagaki, T. Nakanishi, K. Katsuura: Polym. Bull., 9, 502 (1983)

4) H. Yasuda : J. Polym. Sci., Macromol. Revs., 16, 199 (1981)
5) N. Inagaki, M. Matsunaga: Polym. Bull., 13, 349 (1985)

6) N. Inagaki, M. Koyama: J. Polym. Sci., Polym. Chem. Ed., 21 : 183 (1983) : 22, 2083 (1984)

7) H. Yasuda, C.E. Lamaze, K. Sakaoku: J. Appl. Polym. Sci., 17, 137 (1973) : 19, 2845 (1975)

8) N. Inagaki, K. Nejigaki, K. Suzuki : J. Polym. Sci., Polym. Chem. Ed., 21, 3181 (1983)

9) H. Yasuda C.E. Lamaze : J. Appl. Polym. Sci., 17, 201 (1973) : 19, 2157 (1975) : 20, 543 (1976)

10) P. Canepa, M. Nicchina, S. Munari : Chim. Ind., 66, 604 (1984): 寺田一郎, 梶山千里, 原口俊秀: 日本化学 会誌, 1985, 1889

11) M. Yamamoto, J. Sakata, M. Hirai : J. Appl. Polym. Sci., 29, 2981 (1984) : H. Nomura, P.W. Kramer, H. Yasuda: Thin Solid Films, 118, 187 (1984)

12) N. Inagaki, H. Kawai : Sei-i Gakkaishi, 40, T-337 (1984) : J. Memb. Sci., in press

13) S. Shinkai, M. Ishihara, O. Manabe, A. Mizumoto, Y. Osada: Chem. Lett., 7, 1029 (1985)

14）水本 明, 高瀬三男, 長田義仁：Polym. Prep. Jpn., 33, 414 (1984)

15) N. Inagaki: Thin Solid Films, 118, 225 (1984): Appl. Surf. Sci., 24, 163 (1985)

16) E. Kny, L.L. Levenson, W.J. James: Thin Solid Films, 85, 23 (1981)

17) N. Inagaki, Y. Hashimoto: $J$. Polym. Sci., in press

18）鈴木慎一，田坂 茂, 宮田清蔵：高分子論文集, 41,493 (1984) 